\title{
The 2019 Novel Coronavirus (2019-nCoV): Novel Virus, Old Challenges
}

\section{O Novo Coronavírus (2019-nCoV): Novo Vírus, Desafios Antigos}

Raquel DUARTE $\triangle^{1,2}$, Isabel FURTADO ${ }^{3}$, Luís SOUSA ${ }^{4}$, Carlos CARVALHO ${ }^{5}$

Acta Med Port 2020 Mar;33(3):155-157 - https://doi.org/10.20344/amp.13547

Keywords: Coronavirus; Coronavirus Infections; Disease Outbreaks

Palavras-chave: Coronavírus; Infecção por Coronavírus; Surtos de Doenças

In late December 2019, global attention shifted to China after several local health facilities reported clusters of patients with pneumonia of unknown origin epidemiologically linked to the Huanan Seafood Wholesale Market in the municipality of Wuhan, one of the country's central cities. Local health authorities identified a novel betacoronavirus, provisionally called $2019-n C o V,{ }^{1}$ the third zoonotic coronavirus in three decades to cross species infecting humans and raising global health concerns. Chinese government took extraordinary measures, to control the outbreak by closing The Market and by imposing a lockdown, first in Wuhan and later in twelve other Chinese cities. However, by the end of January 2020, there were 9826 confirmed cases $(98.9 \%$ in China) a number that is estimated to be much higher ${ }^{2}$ and that is increasing every hour. The disease has now spread worldwide, with cases confirmed in 23 countries other than China, mainly in Southeast Asia but also in the United States of America and several European countries. On the $30^{\text {th }}$ of January, the World Health Organization's Emergency Committee agreed that the outbreak now meets the criteria for a Public Health Emergency of International Concern. ${ }^{3}$ We are seeing the evolution of what is developing into a serious outbreak.

As the scientific community joins efforts to better understand the origin, pathogenesis and transmissibility of the virus, key questions remain unanswered.

Concerning the origin of the virus, it was initially suggested that snakes were the most probable animal reservoir for the 2019-nCoV. ${ }^{4}$ More recently, researchers concluded that the most closely related genome sequences to the 2019-nCoV were two coronaviruses that originated in bats ( $88 \%$ of shared genetic sequence). ${ }^{5}$ Despite the link to these mammals, several facts suggest that another animal, yet to be discovered, is acting as an intermediate host between bats and humans. ${ }^{5}$

Published data show us that patients typically present with mild respiratory symptoms and fever, often evolving to pneumonia. Complications such as severe pneumonia, acute respiratory distress and cardiac injury have been described in China. ${ }^{6}$ While case fatality rate is as high as $14.6 \%$ in a cohort of 41 patients, ${ }^{6}$ it is close to $2 \%$ considering all reported cases. ${ }^{7}$ These numbers should be interpreted with caution, as the true number of infections and deaths is probably underestimated (mild cases are more likely to be underestimated, which would yield a lower case fatality rate).

Up until now, there is no specific antiviral treatment recommended for 2019-nCoV infection. ${ }^{8}$ The combined use of lopinavir and ritonavir is under study in China and, more recently, it was suggested that baricitinib, a Janus kinase inhibitor should be trialled as a potential therapeutic weapon. ${ }^{9}$

Human-to-human transmission has been occurring not only in China but also in several other countries. ${ }^{7}$ Recent reports estimate that each infected individual generates an additional $1.4-3.9$ cases, ${ }^{10,11}$ and that, in order to control the outbreak, more than $60 \%$ of the transmission should be blocked. ${ }^{12}$ Although it has not been proven so far, it has been stated that asymptomatic persons are potential vehicles of transmission of 2019-nCoV infection, ${ }^{12,13}$ which is an additional challenge to outbreak control.

Some questions such as the true dimension of the outbreak in China, the reason why cases reported outside of China are relatively mild and if the lockdown in China is an effective control measure, are yet to be answered.

Since the $23^{\text {rd }}$ January 2020, China has implemented an unparalleled city-wide quarantine of Wuhan, extended to most of its neighbouring cities and encompassing over 50 million people. However, these interventions have raised concerns regarding both the impact on the affected population's daily subsistence and on the overall economic throughout of the country. Several social distancing measures have been enforced nationally, including suspending school activities, encouraging domiciliary confinement for the general public and using personal protective equipment. ${ }^{14}$

\footnotetext{
1. Departamento de Epidemiologia. Faculdade de Medicina. Universidade do Porto. Porto. Portugal.

2. Instituto de Saúde Pública. Universidade do Porto. Porto. Portugal.

3. Serviço de Infeciologia. Centro Hospitalar Universitário do Porto. Porto. Portugal.

4. Infectious Disease Epidemiology and Preparedness Department. Statens Serum Institut. Copenhaga. Dinamarca.

5. Unidade Multidisciplinar de Investigação Biomédica (UMIB). Instituto de Ciências Biomédicas Abel Salazar. Universidade do Porto. Porto. Portugal.

$\triangle$ Autor correspondente: Raquel Duarte.rdmelo@med.up.pt

Recebido: 05 de fevereiro de 2020 - Aceite: 05 de fevereiro de 2020 | Copyright @ Ordem dos Médicos 2020
} 
Some countries have implemented measures limiting the mobility of people through their borders, from bans on flights from mainland China (e.g. the USA Russia, Japan, Pakistan, Italy and Philippines) to formally closing borders with China (e.g. Russia, North Korea). Other countries (e.g. USA, UK, Italy) have also adopted enhanced screening at points of entry (airport or ports) or on board of outbound flights from China's affected areas. Repatriation of foreign nationals residing in mainland China has also occurred, with varying frameworks and strategies of isolation that, ultimately, have resulted in quarantining these individuals for at least 14 days. ${ }^{15}$

Most experts seem certain this will evolve to be a pandemic, with yet unknown dimensions. To face this challenge, transnational integrated preparedness and contingency plans will have to be implemented and put to the test in short notice. Countries will have to respond promptly to an acute increase in number of cases and the necessary management of patients and their apparently healthy contacts, which implies an adequate preparation of diagnostic and treatment capacity, but also in terms of screening, confinement and follow up of contacts. ${ }^{16}$

This outbreak is raising an alarm about the global preparedness to handle an epidemic or pandemic. The recent Global Health Security Index, which assessed countries' capacity in terms of prevention, detection and reporting, rapid response, health system, compliance with international norms and risk environment, pointed out that national health security is "fundamentally weak around the world". ${ }^{17}$

Preparedness plans should take into account the influence of China on the global economy, trading of goods and services, and the flow of people. If travel bans are already impacting tourism, this epidemic and the enforced quarantine measures will have an impact on the overall economic scenario, forcing us to anticipate shortcomings on the supply of several goods, namely those related to healthcare provision. ${ }^{14}$

Communication is a critical element of preparedness.
Providing up-to-date and reliable information to the general public will be key to maintain the population's trust and steering outbreak control in the right track.

A strong command and control structure is essential to produce serious, clear and simple instructions government and its institutions can to put in place. Communication and education are key to avoid panic and allow the involvement of the population in the control of outbreaks.

As Bill Gates said, "we need to prepare for epidemics the way the military prepares for war. This includes germ games and other preparedness exercises so we can better understand how diseases will spread, how people respond in panic, and how to deal with things like overloaded highways and communications systems. We also need trained medical personnel ready to contain an epidemic quickly". ${ }^{18}$

In Portugal, contingency plans were once again activated and new guidelines for healthcare services and airports were published. However, it is possible that we are still not prepared, even to face a suspected case of 2019-nCoV. The lack of preparedness we witnessed dealing with one single suspect case (luckily not confirmed) should be used to help healthcare services correct their mistakes and to be better prepared. However, those lessons should have been learnt a long time ago, after the emergencies of H5N1 avian influenza, SARS, H1N1 Pandemic and MERS-CoV. More than worrying about the basic reproductive number, that seems to be low but should suffice to generate a pandemic in a fully susceptible population, we should be making sure that the country is ready to contain the disease promptly after its introduction via a suspected case or an apparently healthy contact. Important concerns around civil liberties should be considered, but the defence of public health should always take precedence.

The 2019-nCoV epidemic is also a test to our ability to face a threat that will repeat itself over time. Each time, we should learn with our mistakes and be better prepared than before.

\section{REFERENCES}

1. Zhu N, Zhang D, Wang W, Li X, Yang B, Song J, et al. A novel coronavirus from patients with pneumonia in China, 2019. N Engl J Med. $2020 \mathrm{~N}$ Engl J Med. 2020 (in press). doi: 10.1056/NEJMoa2001017.

2. Imai ND, Cori A, Riley S, Ferguson NM. Report 2: Estimating the potential total number of novel Coronavirus cases in Wuhan city, China. 2020. [accessed 2020 Jan 31]. Available from: https://www.imperial. ac.uk/mrc-global-infectious-disease-analysis/news--wuhancoronavirus/.

3. World Health Organization. Statement on the second meeting of the International Health Regulations (2005) Emergency Committee regarding the outbreak of novel coronavirus (2019-nCoV). 2020. [accessed 2020 Jan 31]. Available from: https://www.who.int/news-room/detail/30-012020-statement-on-the-second-meeting-of-the-international-healthregulations-(2005)-emergency-committee-regarding-the-outbreak-ofnovel-coronavirus-(2019-ncov).

4. Ji W, Wang W, Zhao X, Zai J, Li X. Homologous recombination within the spike glycoprotein of the newly identified coronavirus may boost crossspecies transmission from snake to human. J Med Virol. 2020 (in press). doi: 10.1002/jmv.25682.

5. Lu R, Zhao X, Li J, Niu P, Yang B, Wu H, et al. Genomic characterisation and epidemiology of 2019 novel coronavirus: implications for virus origins and receptor binding. Lancet. 2020 (in press). doi: 10.1016/

S0140-6736(20)30251-8.

6. Huang C, Wang Y, Li X, Ren L, Zhao J, Hu Y, et al. Clinical features of patients infected with 2019 novel coronavirus in Wuhan, China. Lancet. 2020 (in press). doi: 10.1016/S0140-6736(20)30183-5.

7. World Health Organization. Novel Coronavirus(2019-nCoV) Situation Report - 15. 2020. [accessed 2020 Jan 31]. Available from: https://www. who.int/docs/default-source/coronaviruse/situation-reports/20200204sitrep-15-ncov.pdf?sfvrsn=88fe8ad6_2.

8. Centers for Disease Control and Prevention. 2019-nCoV Prevention \& Treatment. 2020. [accessed 2020 Jan 31]. Available from: https://www. cdc.gov/coronavirus/2019-ncov/about/prevention-treatment.html.

9. Richardson PG, Griffin I, Tucker C, Smith D, Oechsle O, Phelan A. Baricitinib as potential treatment for 2019-nCoV acute respiratory disease. Lancet. 2020 (in press). doi: 10.1016/S0140-6736(20)301835.

10. Li Q, Guan X, Wu P, Wang X, Zhou L, Tong Y, et al. Early transmission dynamics in Wuhan, China, of novel coronavirus-infected pneumonia. N Engl J Med. 2020 (in press) doi: 10.1056/NEJMoa2001316.

11. Imai NC, Dorigatti I, Baguelin M, Donnelly C, Riley S, Ferguson NM. Report 3: Transmissibility of 2019-nCoV. 2020. [accessed 2020 Jan 31]. Available from: https://www.imperial.ac.uk/media/imperial-college/ 
medicine/sph/ide/gida-fellowships/Imperial-2019-nCoV-transmissibility. pdf.

12. Rothe C, Schunk M, Sothmann P, Bretzel G, Froeschl G, Wallrauch C, et al., Transmission of 2019-nCoV infection from an asymptomatic contact in Germany. N Engl J Med. 2020 (in press). doi: 10.1056/ NEJMc2001468.

13. Kupferschmidt K. Study claiming new coronavirus can be transmitted by people without symptoms was flawed. ScienceMag. 2020. [accessed 2020 Jan 31]. Available from: https://www.sciencemag. org/news/2020/02/paper-non-symptomatic-patient-transmittingcoronavirus-wrong.

14. Kickbusch I, Leung G. Response to the emerging novel coronavirus outbreak. BMJ. 2020;368:m406.
15. Mahase E. China coronavirus: what do we know so far? BMJ. 2020;368:m308.

16. Wu JT, Leung K, Leung GM. Nowcasting and forecasting the potential domestic and international spread of the 2019-nCoV outbreak originating in Wuhan, China: a modelling study. Lancet (in press). doi: 10.1016/ S0140-6736(20)30260-9.

17. Johns Hopkins Center for Health Security. Global Health Security Index. 2019. [accessed 2020 Jan 31]. Available from: https://www.ghsindex. org/wp-content/uploads/2019/10/2019-Global-Health-Security-Index. pdf.

18. Bill Gates. Speech at the Munich Security Conference. 2017. [accessed 2020 Jan 31]. Available from: https://www.gatesfoundation.org/MediaCenter/Speeches/2017/05/Bill-Gates-Munich-Security-Conference. 